\title{
Raputallang sebagai Konsep Konseling Kontekstual di Masyarakat Toraja
}

Ayub Alexander

Pascasarjana Sosiologi Agama, Universitas Kristen Satya Wacana, Salatiga, Jawa Tengah ayubsambarado@gmail.com

\begin{abstract}
The Toraja people understand Raputallang as an expression of personification (symbolic) in which it expresses the meaning of family relations that are built based on flesh-blood relations (genealogy). The purpose of this research is to explain the concept of Raputallang as a counseling media for the people of Toraja. This research is motivated by the lack of impact and the limited reach of the counseling process carried out by the church to the Toraja people who are facing problems. Therefore, it is necessary to develop counseling media that can reach and provide a more effective impact to help the people of Toraja to improve the value of life which had declined due to the problems they faced. This study, using the theory of Community Counseling, was developed by Judith A. Lewis and colleagues. This paper use a qualitative research with a descriptive approach. The source of this research information are to minaa '(traditional leaders) and cultural observers in Toraja. This research shows that Raputallang becomes or is used as a medium for community counseling through a cultural awareness approach.
\end{abstract}

Keywords: community counseling; contextual counseling; raputallang; Toraja society

\begin{abstract}
Abstrak: Masyarakat Toraja memahami Raputallang sebagai ungkapan personifikasi (simbolik) yang di dalamnya mengungkapkan makna relasi kekeluargaan yang terbangun berdasarkan hubungan darah daging (genealogi). Tujuan penelitian ini untuk mengkaji Raputallang sebagai media konseling masyarakat Toraja. Penelitian ini dilatar belakangi oleh kurangnya dampak dan terbatasnya jangkauan dari proses konseling yang dilakukan oleh gereja kepada masyarakat Toraja yang sedang menghadapi permasalahan. Oleh sebab itu, perlu dikembangan media konseling yang bisa menjangkau dan memberikan dampak yang lebih efektif untuk membantu masyarakat Toraja meningkatkan nilai hidup yang sempat menurun akibat permasalahan yang dihadapinya. Penelitian ini, menggunakan teori Konseling Masyarakat yang di Kembangkan oleh Judith A. Lewis dan rekan-rekan. Penelitian kualitatif dengan pendekatan deskriptif. Sumber informasi penelitian ini ialah to minaa' (tokoh adat) dan pemerhati budaya yang ada di Toraja. Penelitian ini menunjukkan bahwa Raputallang menjadi atau dijadikan sebagai media konseling masyarakat melalui pendekatan kesadaran budaya.
\end{abstract}

Kata Kunci: konseling kontekstual; konseling masyarakat; masyarakat Toraja; raputallang

\begin{tabular}{llll}
\hline Article History : & Received: 01-08-2019 & Revised: 29-11-2019 Accepted: 13-12-2019
\end{tabular}




\section{Pendahuluan}

Masuknya Kekristenan pada awal abad ke-20 di Tana Toraja melalui organisasi penginjilan (GZB) dari Belanda telah menghasilkan begitu banyak perubahan dalam struktur kehidupan bermasyarakat di Tana Toraja, salah satunya adalah perubahan pada segi kepercayaan masyarakat Toraja. Masyarakat Toraja yang dulunya mayoritas berkepercayaan Aluk Todolo kemudian memilih untuk masuk ke dalam agama Kristen. Perpindahan agama yang dilakukan oleh masyarakat pada masa itu, dari Aluk Todolo ke agama Kristen juga secara tidak langsung ikut mempengaruhi kebudayaan dari masyarakat Toraja. Kebudayaan Toraja yang didasarkan pada pemahaman Aluk Todolo secara perlahan-lahan disingkirkan oleh kebudayaan yang didasarkan pada pemahaman Kristen yang berwajah barat. Salah satu cara yang digunakan untuk menyingkirkan kebudayaan Toraja yang didasarkan pada pemahaman Aluk Todolo adalah dengan merekonstruksi pemahaman di kalangan masyarakat Toraja yang telah berpindah dari Aluk Todolo ke kekristenan dengan menggunakan standarisasi kekristenan.

Secara tidak langsungsung pola keidupan masyarakat Toraja terseret mengikuti arus yang telah dibangun berdasara pada nilai ajaran Kristen. Keadaan tersebut tentunya lambat laun menggeser kebudayaan, memberi batas pemisah antara yang bersifat tradisional dan berbau keagamaan (Kristen). Pemisahan tersebut membuat masyarakat Toraja "kaku” untuk memaknai, menghidupi kembali nilai-nilai kebudayaan karena dalam pemahamannya dengan beragama Kristenan mampu mengatasi segala permasalahan.

Masuk serta berkuasanya budaya barat melalui wajah kekristenan membuat sebagian kebudayaan Toraja menjadi termarginalkan dan bahkan terdiskriminasi di negeri sendiri, hal ini pada akhirnya menjadikan masyarakat Toraja mengalami 'amnesia' terhadap kebudayaannya sendiri, sehingga tanpa disadari dan tak jarang terciptalah masyarakat Toraja yang mengalami kegagalan dalam memahami kebudayaannya. Salah satu contoh terjadinya rekonstruksi pada kebudayaan Toraja, terlihat dalam ritus badong, pada dasarnya badong dikalangan masyarakat Toraja dinyanyikan dengan menggunakan huruf-huruf vocal, yang intinya berisi untaian relasi sang mendiang kepada sesama, doa buat keluarga yang ditinggalkan serta permohonan kepada sang khalik menyangkut keselamatan sang mendiang. Masyarakat Kristen Toraja, badong tetap dilakukan, tetapi pada umumnya dikalangan masyarakat Kristen, lagu yang dinyanyikan dalam ritus badong menggunakan lagu-lagu kristiani baik itu yang terambil dalam Kidung Jemaat maupun Mazmur Pujian, hal itu di akibatkan oleh pemahaman yang ada bahwa untaian lagu yang ada di balik nyanyian dalam ritus badong berisi pemujaan kepada sang "dewa", sehingga tak layak di ikuti oleh umat kristen, sehingga harus diganti.

Agama Kristen yang bernuansa kebudayaan barat pada akhirnya tampil mendominasi segala lini kehidupan masyarakat Toraja sampai sekarang, hal ini ditandai dengan pola kehidupan kekristenan yang berciri khas barat yang teramat kental di kalangan masyarakat Toraja, terutama dalam pemahaman-pemahaman konseptual dan 
praktik-praktik keagamaan saat ini di Toraja. Salah satu bukti ialah, praktik konseling yang dilakukan oleh Kekristenan, dalam hal ini secara khusus oleh Gereja Toraja yang lahir dan berdiri dari pekabaran Injil GZB kepada masyarakat yang mengalami masalahmasalah dalam kehidupan, di mana Gereja Toraja dalam praktik konselingnya masih menerapkan pola barat yang menjadi warisan Zending dalam proses konseling, dimana dalam praktiknya konseling yang diterapkan masih menggunakan pendekatan konseling Kristen yang hanya mengakomodir sesama orang Kristen saja. sehingga proses konseling yang ada memiliki keterbatasan jangkauan, dan hanya bisa dinikmati dan dilakukan kepada orang-orang yang se-agama dalam lingkup masyarakat Toraja padahal dalam tataran masyarakat Toraja saat ini, Kekristenan bukan satu-satunya agama di Toraja yang perlu mendapatkan perhatian (konseling).

Masyarakat Toraja kini dihantui dengan masalah-masalah yang terjadi dalam segala lini kehidupannya, yang berujung pada penurunan nilai (value) hidup, seperti: maraknya terjadi tindakan kekerasan yang berujung pada perkelahian dan pembunuhan, perebutan harta warisan, dan korupsi. Fakta yang terjadi di Toraja seperti yang disebutkan di atas sebenarnya ingin memperlihatkan bahwa problematika hidup yang membelenggu membuat masyarakat Toraja memerlukan dan membutuhkan konseling yang benar-benar mampu membantu mereka untuk mengatasi permasalahan yang masyarakat hadapi, tanpa melihat keyakinan yang dianut. Sehingga mereka mampu keluar dari permasalahan hidup yang tengah menjerat kehidupan mereka.

Karena pada hakikatnya konseling masyarakat merupakan pelayanan dalam rangka menolong sesama yang dilakukan dalam bentuk komunikasi terapeutik antara konselor dengan konseli, di mana dalam komunikasi tersebut seorang konselor akan mencoba untuk membantu dan membimbing konseli ke dalam suatu suasana percakapan konseling yang ideal (Conducive atmosphere) yang pada akhirnya dapat membantu konseli untuk dapat mengenal dan mengerti apa yang sedang terjadi dalam dirinya, menyangkut persoalan yang ia sedang hadapi, kondisi hidupnya, sehingga mengapa ia merespon semua itu dengan pola pikir, perasaan dan sikap tertentu.

Selain itu, proses konseling masyarakat merupakan sebuah upaya yang dilakukan dalam rangka untuk memanusiakan manusia, sehingga dalam proses konseling mengandung makna pemberdayaan terhadap manusia. Hal demikan menghadirkan pemahaman bahwa melalui proses konseling, diharapkan masyarakat dapat memiliki kesadaran dan rasa keberdayaan yang pada akhirnya akan benar-benar menuntun masyarakat untuk bisa keluar dari permasalahan hidup yang dihadapi.

Sebenarnya, seperti yang sudah dijelaskan di atas bahwa di kalangan masyarakat Toraja proses konseling telah diberikan oleh gereja, tetapi dalam pengamatan penulis, proses konseling yang ada belum memberikan dampak yang signifikan bagi kehidupan masyarakat di Toraja. Hal itu ditandai dengan masih maraknya bahkan boleh dikatakan meningkatnya tindakan amoral, seperti, korupsi, pembunuhan, pemerkosan, 
percabulan, penganiyayan, homo seksual yang melibatkan masyarakat Toraja, bahkan menurut catatan kepolisian, angka bunuh diri di Toraja pada tahun 2019 meningkat.

Menurut observasi awal penulis, kurang efektifnya pelayanan konseling yang dilaksanakan oleh Gereja dikarenakan pendekatan yang digunakan dalam proses konseling bersifat kaku, formalistik, hanya menggunakan Alkitab sebagai pedoman dalam memberikan arahan kepada konseli, dan tak kalah pentingnya masih bersifat individualistik sebagaimana warisan konseling kristen ala barat, yang notabene bertolak belakang dengan karakteristik orang Indonesia terlebih khusus masyarakat Toraja yang hidup dalam keadaan majemuk. Sehingga proses konseling yang terjadi tidak membawa perubahan yang signifikan bagi kehidupan masyarakat Toraja. Hal ini penulis saksikan, beberapa masalah yang gereja tangani, baik itu yang bersifat ersonal maupun komunal konseli hanya diperhadapkan pada satu persfektif konseling yaitu "kembali ke Alkitab", tanpa membuka ruang terhadap nilai kearifan yang dimiliki oleh kebudayaan.

Menurut Engel, konseling kristen ala barat, dilatar belakangi oleh budaya Eropa dan Amerika yang lebih bersifat individualis, egaliter serta otonom,sementara kebudayaan bangsa Indonesia dan terlebih khusus masyarakat Toraja justru hidup dalam karakteristik sebaliknya dari budaya Eropa dan Amerika dan lebih menjunjung tinggi prinsip komunal dan determenistik. Oleh sebab itu, maka perlunya dikembangkan praktik konseling yang menggunaka kearifan lokal sebagai media dalam pruses konseling, sebagai upaya menghadirkan proses konseling yang lebih menjawab kebutuhan serta karakteristik masyarakat Toraja.

Toraja memiliki banyak kebudayaan yang dapat dijadikan sebagai sebuah pendekatan dalam proses konseling. Dalam kebudayaan Toraja banyak hal yang dapat dijadikan sebagai pelajaran dan makna hidup untuk dijadikan sebagai landasan menghadapi berbagai problematika dalam kehidupan. Salah satu kebudayaan yang dapat dijadikan sebagai landasan berpikir praktik konseling bagi orang Toraja adalah Raputallang yang dinilai dapat mengakomodir masyarakat Toraja secara menyeluruh tanpa membedakan agama dan keyakinan seseorang.

Raputallang merupakan ungkapan personifikasi yang merujuk pada konsep kekeluargaan Masyarakat Toraja. Hal ini dipertegas oleh Oktaviandi Rantelino dalam tesisnya, ia mengatakan bahwa Raputallang merupakan simbol bagi masyarakat Toraja yang dihidupi dalam konsep kekeluargaan. Kata Raputallang merupakan saduran dari dua kosa kata yaitu Rapu' yang berarti Rumpun dan Tallang berarti Bambu, sehingga ketika kedua kosa kata ini digabungkan terbentuklah kata Raputallang yang memiliki arti rumpun bambu yang dikonotasikan dengan rumpun keluarga. Sebagaimana etimologinya maka dipastikan bahwa kata Raputallang merupakan personifikasi dari tanaman modular bambu yang banyak tumbuh di wilayah Tanah Toraja. Penggunaan kata Tallang dalam istilah ini, menurut Yohanes Ruruk tak lain dari keguanaan bambu yang multifungsi bagi kehidupan masyarakat Toraja. 
Raputallang menyimbolkan keturunan dari satu unsur asal (keluarga) sehingga bagi masyarakat Toraja simbol Raputallang mengandung makna filosofi sebagai kerukunan yang di dalamnya sangat menjunjung tinggi kebersamaan dalam komunitas keluarga. Selain itu masyarakat Toraja meyakini bahwa simbol Raputallang di dalamnya banyak mengandung nilai-nilai spiritual, diantaranya: Kasirampunan, Mabulo Lollong, Kinawa, Siangkaran, Sitiroanan, Tuo Lan Mintu A'gan, Keangga, yang dijadikan sebagai sebuah cara hidup masyarakat toraja dalam menjaga kesatuan keluarga untuk menghadapi berbagai masalah hidup. Tidak sampai di situ, Raputallang dalam komunitas masyarakat Toraja memiliki fungsi sebagai simbol penyelesaian masalah, introspeksi diri, perekat relasi, kontrol sosial. Dengan demikian semua nilai-nilai yang ada diatas akan dicapai jika kesadaran-penghayatan terhadap Raputallang diakomodir sebagai suatu pendekatan dalam penyelesaian masalah.

\section{Metode Penelitian}

Membangun konseling berlandaskan pada pendekatan konsep Raputallang adalah sesuatu yang semestinya dipraktikkan dalam komunitas hidup orang Toraja terutama dalam menghadapi problem hidup yang kompleks di masa kini. Untuk mendapatkan konsep mengenai Raputallang yang berkaitan dengan praktik konseling masyarakat Toraja bukanlah suatu hal yang mudah, mengingat bahwa belum pernah ada penelitian yang menghubungkan antara konsep Raputallang dan praktik konseling masyarakat di Toraja, oleh karena itu maka dalam artikel kali ini penulis akan lebih banyak menggunakan teknik pengumpulan data yang bersifat deskriptif melalui pengamatan, melalui partisipasi langsung dan juga melalui wawancara kepada tokoh-tokoh masyarakat di Toraja untuk menemukan data seobjektif mungkin.

\section{Raputallang dan Konseling Masyarakat}

Raputallang pada hakikatnya adalah juga konseling masyarakat, jika konseling masyarakat pada umumnya menghendaki agar kehidupan masyarakat berjalan harmonis, maka raputallang sebagai filosofi hidup kekeluargaan yang harmonis juga dapat disebut sebagai praktik konseling masyarakat yang sudah berakar pada nilai dan jati diri orang Toraja.

Sebagaimana disadari sebelum masuk dan berkembangnya kekristenan, masyarakat Toraja merupakan sekumpulan individu yang menghidupi nilai-nilai kebudayaan cukup ketat, bagi mereka kebudayaan merupakan hal penting yang harus terus dipelihara dan dihidupi, sebab dalam kehidupan mereka, kebudayaan turut serta mengkonstruksi, membentuk, membimbing serta memandu kehidupan baik secara individu maupun komunal. Dalam kehidupan sehari-hari, perilaku serta sikap hidup masyarakat Toraja banyak dibentuk oleh kebudayaan, dari banyaknya kebudayaan yang membentuk pola hidup mereka, Raputaallang menjadi salah satu kebudayaan yang turut serta membentuk perilaku hidup masyarakat Toraja, khususnya dalam hal membangun relasi yang harmonis di tengah-tengah kehidupan keluarga. 
Bagi masyarakat Toraja sebagai mana yang dikemukakan oleh Daud Pangarungan, Raputallang merupakan kebudayaan yang dimiliki oleh masyarakat Toraja yang cukup berperan penting dalam mengajarkan, membimbing, mengkonstruksi dan bahkan menegur kehidupan masyarakat. Dalam upaya melengkapi argumentasi di atas Urbanus Sampe Rante dan Yohanis Ruruk menyatakan bahwa, melalui nilai yang terakomodir di dalam Raputallang "kita" di ajarkan untuk bagaimana menjaga kebersamaan, bersikap jujur, bijaksana, tidak mudah putus asa, saling menopang dan bahkan berguna bagi orang lain. Dapat dikatakan bahwa Raputallang dalam masyarakat Toraja tidak hanya menjadi kebudayaan yang hadir begitu saja, tetapi memiliki peran penting yang mengajak setiap orang Toraja untuk menghayati kehidupannya secara otentik bagi dirinya sendiri, masyarakat dan alam semesta, untuk suatu kehidupan yang harmonis.

Memaknai Raputallang sebagai bagian dari praktik konseling masyarakat sebenarnya adalah salah satu tahapan untuk menciptakan masyarakat Toraja yang harmonis. Hal ini sebenarnya sejalan dengan konsep yang disampaikan oleh Esteban bahwa dalam pendekatan praktik konseling masyarakat di abad 21 ini konsep atau model yang diperlukan untuk menganalisa masalah yang timbul di masyarakat dan juga pendekatan solusi pemecahan masalah yang dibutuhkan adalah pendekatan ekologiskultural. Dari pernyataan Esteban dapat dipahami bahwa pendekatan ekologis kultural dalam praktik konseling masyarakat merupakan sebuah upaya konseling yang menggunakan kebudayaan dimana konseli bertumbuh, sebagai sarana untuk membantu konseli keluar dari masalah yang dihadapi. Dengan pendekatan ekologis cultural diharapkan agar konseling masyarakat dapat berperan sebagai agen perubahan yang dapat memberikan pengaruh secara kompreeherensif terhadap kehidupan masyarakat dengan mempertimbangkan beberapa faktor yang merupakan komoditi asli dari masyarakat tersebut misalnya adalah kebudayaan atau kearifan lokal.

Hal ini senada dengan apa yang disampaikan oleh Engel, bahwa dalam praktik konseling masyarakat, budaya atau kearifan lokal merupakan prinsip utama konseling pada abad dua puluh satu ini, karena masyarakat akan lebih mudah terbuka terhadap konsep kearifan lokal ketimbang pada kebudayaan luar. Selain itu, secara psikologis, kedekatan antara diri dan kebudayaan membuat orang cepat insyaf,hal ini disebabkan oleh sifat manusia itu sendiri yang lebih cepat akan memahami dan mengerti akan suatu hal jika disuguhkan suatu hal yang dapat membangkitkan kesadaran kolektif sebagai auto kritik.

Dalam perspektif masyarakat Toraja, praktik konseling melalui pendekatan kekeluargaan adalah salah satu cara yang dapat dicoba untuk membantu masyarakat Toraja untuk dapat lebih cepat memahami dan menemukan jalan keluar bagi permasalahan yang dihadapi mengingat bahwa masyarakat Toraja adalah masyarakat yang dibentuk dan dibangun dengan nilai-nilai kekeluargaan yang kuat. Sebagai media untuk konseling, beberapa konsep yang bisa diambil dari Raputallang yang sejalan dengan prinsip-prinsip konseling masyarakat adalah sebagai wadah pendampingan bagi masyarakat. 
Salah satu prinsip konseling masyarakat adalah pendampingan dalam rangka memberdayakan masyarakat untuk hidup yang menghidupkan. Prinsip ini sejalan dengan peran dari kebudayaan dalam masyarakat sebagai pendampingan bagi masyarakat, hal iniseperti yang dijelaskan oleh Clyde Kluckhon mengenai kebudayaan, sebagaimana yang dicatat oleh Clifford Geertz dalam bukunya yang menjelaskan bahwa kebudayaan merupakan suatu mekanisme dalam rangka melakukan penataan tingkah laku yang bersifat normatif, seperangkat teknik untuk menyesuaikan diri dengan baik kepada lingkungan luar maupun orang lain.

Raputallang sebagai sebuah kebudayaan yang dimiliki oleh masyarakat Toraja, juga tentu memiliki fungsi sebagai sebuah kebudayaan yakni sebagai pendampingan. Sebagai sebuah kebudayaan, Raputallang memiliki banyak nilai yang dijadikan oleh masyarakat Toraja sebagai panduan dalam mengkontruksi kehidupannya menjadi lebh baik, misalnya nilai kejujuran, dalam hal ini melalui simbol Raputallang orang Toraja di tuntut untuk selalu berlaku jujur.

Sebagai sebuah kebudayaan yang memiliki peran pendampingan dalam rangka mengkontruksi kehidupan masyarakat Toraja, maka Raputallang dalam komunitas masyarakat Toraja dapat dijadikan sebagai:

\section{Simbol Penyelesaian Masalah}

Masalah merupakan sesuatu hal yang dapat merusak relasi dalam kehidupan masyarakat, dengan keadaan ini, maka diharapkan masalah yang terjadi dapat diselesaikan dengan cara-cara bijaksana dengan menggunakan waktu yang singkat sehingga tidak menimbulakan masalah baru yang dapat lebih merusak hubungan diantara masyarakat.

Dalam kaitannya sebagai wadah pendampingan Raputallang memiliki fungsi untuk mengatur kehidupan masyarakat menjadi lebih baik. Sebagaimana fungsinya untuk mengatur kehidupan sosial, Raputallang memberikan pemahaman kepada masyarakat Toraja secara simbolik dalam menyelesaikan suatu masalah yang dihadapi dan terjadi diantara mereka harus terlebih dahulu menggunakan pendekatan kekeluargaan, sebelum memilih jalur hukum sebagai sebuah upaya penyelesaian masalah yang ditemui. Dalam kaitannya sebagai simbol penyelesaian masalah, Koni menyatakan bahwa pantang bagi masyarakat Toraja untuk menyelesaikan masalah dengan jalur hukum sebelum menempuh jalur kekeluargaan.

Dengan mendengar dan memahami mengenai Raputallang masyarakat Toraja, dalam kesadaran asalinya bahwa siapa saja yang bertikai pantang untuk memperpanjang masalah yang terjadi pada meja hukum. Orang Toraja lebih memilih untuk menyelesaikan pertikaian yang terjadi diantara mereka dengan nuansa kekeluargaan. Dalam hal ini, keluarga berkumpul, rembuk bersama dengan mengedapankan asas-asas kekeluargaan yang terkandung dalam konsep Raputallang. 


\section{Simbol Intropeksi Diri}

Intropeksi diri merupakan upaya peninjaun terhadap perbuatan, sikap, kelemahan, dan sebagainya yang dilakukan atas diri kita sendiri. Raputallangdapat digunakan sebagai simbol bagi orang Toraja untuk menuntun dan mengajarkan setiap individu pada kelompok masyarakat dalam menjalani kehidupan dengan kebenaran, memiliki fungsi sebagai alat yang digunakan untuk melakukan intropeksi diri.

Dalam paradigma masyarakat Toraja dengan mendengarkan serta memahami Raputallang (saluan rara buku) dan melihat pohon bambu yang dijadikan sebagai objek dari simbol tersebut masyarakat diajarkan untuk melakukan upaya peninjauan kembali atas sikap buruk yang hendak dilakukan kepada keluarga maupun orang lain, dalam bahasa Arung menyatakan saluan rara buku atau Raputallang, unnadaikita'tan lilanta' ke ladenki lambuangan kada burukta keditandai Raputallangta, na'adaiki sipakamasei, na'daiki tatan gora-goranta ke lasisengkean ki sola Raputallangt. Artinya, melalui Raputallang kita diajar untuk mengontrol lidah sebelum mengatakan sesuatu hal yang buruk kepada keluarga, kita diajarkan saling mengasihi, mengontrol ucapan saat hendak bermasalah dengan keluarga.

Secara sederhana arti dari teks bahasa Toraja diatas hendak menegaskan bahwa melalui simbol Raputallang masyarakat Toraja diberikan pengajaran untuk selalu melakukan introspeksi diri sebelum melakukan tindakan yang tidak terpuji.

\section{Simbol Perekat Relasi}

Kehidupan sosial sangat dipengaruhi oleh relasi yang terjadi antara satu dengan yang lainnya. Dalam tataran praksis relasi yang ada di masyarakat menentukan cara individu satu berperilaku kepada individu yang lain. Jika hubungan yang ada diantara individu satu dengan individu yang lain kurang baik bisa dipastikan bahwa perilaku seseorang kepada orang lain kurang baik. Dengan keadaan seperti itu maka dibutuhkan media untuk menjadi motor penggerak dalam membangun dan merekatkan relasi yang terjadi ditengah-tengah masyarakat. Sebagaimana asalinya saat konflik terjadi ditengah-tengah keluarga Parengnge atau tokoh adat melakukan mediasi, kemudian di dalamnya Parengnge menjelaskan konsep Raputallang, lalu melihat secara rinci duduk perkara, memberi solusi memutuskan, membuat kesepakatan bersama, mendamaikan yang ditandai dengan salaman atau pelukan dan diakhiri dengan makan bersama. Catatan penting dari proses ini keputusan yang telah dibuat bersama tidak boleh dilanggar, apabila dilanggar maka akan mendapatkan sangsi sebagaimana yang telah diatur melalui kesepakatan. Hal yang terpenting juga dari proses ini ruang untuk membenci atau mendendam tidak diperbolehkan terjadi bagi kedua pihak yang bertikai.

Sebagai wadah pendampingan yang menuntut masyarakat Toraja untuk tetap mempererat relasi kekeluargaan yang ada dalam upaya mencegah dan mengatasi terjadinya perpecahan serta pertikaian diantara individu yang ada dalam satu komunitas masyarakat maupun keluarga. Dalam konteks kehidupan masyarakat Toraja, konsep Raputallang cukup memberikan sumbangsi yang besar dalam menciptakan relasi yang baik di tengah-tengah masyarakat. Sebab melalui paradigama Raputallang 
orang tersadar bahwa relasi yang mereka jalani ini bukan merupakan relasi yang biasa melainkan relasi yang terbangun atas dasar adanya hubungan darah daging diantara mereka, sehingga membuat masyarakat enggan untuk memperpanjang masalah yang ada diantara mereka. Makna tersebut terkandung dalam penrnyataan Urbanus Ladi pa umbai na mesa' ki to siulu (mau diapakan lagi kita adalah orang yang bersaudara). Jadi dalam pernyataan tersebut memberikan gagasan bahwa masalah yang ada diantara masyarakat harus diselesaikan.

\section{Simbol Kontrol Sosial}

Dalam kehidupan masyarakat kontrol sosial sangat diperlukan sebagai upaya menghindarkan warga atau individu untuk tidak berbuat diluar norma-norma kemasyarakatan yang berlaku dalam satu wilayah dimana individu itu melangsungkan kehidupannya. Masyarakat Toraja yang hidup dalam satu komunitas besar terdapat banyak media yang dapat dijadikan sebagai pengontrol sosial, salah satunya ialah simbol Raputallang.

Raputallang merupakan personifikasi dari rumpun keluarga yang didalamnya mengandung banyak nilai yang dapat dijadikan sebagai pengontrol perilaku sosial. Salah satunya ialah nilai kejujuran yang selaluh mendampingi masyaraat Toraja untuk selalu berbuat jujur. Dengan demikian Raputallang memiliki fungsi sebagai instrument kontrol sosial dalam kalangan masyarakat Toraja, baik itu secara individu maupun komunal.

Dengan Raputallang secara simbolik masyarakat Toraja dibimbing untuk menjalankan hidup sebagaimana mestinya (sesuai aturan norma yang berlaku). Melalui nilainilai yang terkandung dalam Raputallang masyarakat Toraja diarahkan agar bersikap jujur, bijaksana, saling menopang, melindungi, mampu bertahan hidup dalam segala kondisi, dan mampu menjadi saluran berkat bagi yang lain.

\section{Raputallang dan Strategi Konseling Masyarakat}

Raputallang merupakan simbol ditengah-tengah orang Toraja, mengandung nilai-nilai yang dapat mengkontruksi kehidupan masyarakat untuk menjadi lebih baik. Dalam strategi terfokus manusia diarahakan untuk kembali pada unsur kebudayaan. Manusia kembali diingatkan mengenai esensi nilai yang terkandung dalam ikatan tali persaudaraan pada konsep Raputallang. Dalam strategi ini Raputallang diharapkan menjadi instrumen pemersatu yang mengajak manusia untuk mengenang asalnya, statusnya, hingga kedudukannya di dalam keluarga. Tidak hanya sampai di situ, Raputallang juga mengakomodir masyarakat agar terfokus secara kolektif untuk mengambil bagian atau peran dalam penyelesaian masalah, singkatnya semua unsur dalam masyarakat turut dilibatkan, termasuk benda-benda kebudayaan juga hewan sebagai simbol perdamainan.

Sedangkan, jika berbicara mengenai strategi berbasis luas, manusia Toraja lewat tuturan lisan, sejak kecil selalu diceritakan menganai silsilah kekeluargaan. Silsilah ini, 
memuat berbagai hal seperti asal usul, marga, persilangan marga, hingga domisili. Disamping itu, makna, nilai, keutuhan mengenai kekeluargaan juga dituturkan sebagai sesuatu yang bersifat edukatif. Hal ini dilakukan tidak hanya dimaksudkan agar saling mengenal, namun juga berorientasi pada kompetensi, yang mendorong suatu keterampilan. Misalnya, jika diceritkan bahwa neneknya dahulu adalah seorang yang baik dan pintar. Cerita ini juga diharapkan merasuk agar setiap keturunan mewarisi sikap baik dari leluhurnya. Di sisni manusia toraja diharapkan secara individual mampu mengembangkan pikirannya, potensinya, bakat atau minatnya dalam menjalani kehidupan berserta masalah yang akan dihadapinya kelak.

Konseling masyarakat pada dasarnya diakomodasi oleh kompetensi multicultural. Kompetensi multicultural disini dipahami sebagai pengetahuan yang dimiliki oleh seorang konselor untuk memahami konseli sebagai sebuah subjek yang tumbuh dan berkembang dengan beragam latar belakang yang berebeda, sehingga dibutuhkan kemampuan oleh seorang konselor dalam memahami latar belakang yang melekat pada seorang konseli, Hal tersebut sejalan dengan penyataan Lewis yang disadur oleh Engel dalam bukunya.

Lewis dalam Engel menyatakan bahwa kompetensi multicultural didasarkan pada sebuah kesadaran yang dimiliki oleh konselor mengenai nilai-nilai budaya serta bias budaya, selain itu seorang konselor harus juga menaruh kesadaran terhadap pandangan yang diutarakan oleh konseli, sehingga berdampak pada strategi intervensi yang berdasar pada budaya klien yang meliputi kategori etitudes, keyakinan, pengetahuan serta ketereampilan yang dimiliki olehh seorang konseli. Jadi dapat dikatakan bahwa kompetensi multicultural merupakan pemahaman menyangkut keberagaman budaya dalam arti luas, misalnya: pendidikan, status sosial, agama, etnis, lingkungan sosial, perilaku sosial dan lain-lain yang dapat menjadi pemicu lahirnya masalah dalam diri klien.

Sejalan dengan hal yang digambarkan oleh pendapat diatas juga terdapat dalam Raputallang. Sebagai sebuah kebudayaan yang dijadikan masyarakat Toraja sebagai suatu media untuk mengonstruksi hidup dan kehidupannya, Raputallang pada dasarnya menjangku kebeberagaman budaya yang terdapat dibalik kehidupan masyarakat Toraja hari ini, misalnya: agama, kondisi hidup, pendidikan, stratifikasi sosial, usia, jenis kelamin, dialektika, aturan keadaan ekonomi dan lain sebagainya. Dengan melihat kesamaan yang ada dapat dikatan bahwa pada dasarnya Raputallang memiliki karakteristik kompetensi multicultural sebagaimana yang dimahksudkan dalam paradigma konseling masyarakat yang ditekankan oleh Lrewis, kompetensi multicultural memiliki sepuluh karakteristik yang coba ia singkat dengan kata RESPECTFUL.

Raputallang dalam komunitas masyarakat Toraja dipahami sebagai simbol yang didalamnya mengandung nilai-nilai kehidupan yang menghantarkan orang Toraja mampu membangung makna hidup yang telah terampas oleh perilaku pribadi, maupun perilaku orang lain dalam upaya mengembalikan kebersamaan yang terjalin ditengahtengah keluarga maupun masyarakat Toraja. Itu berarti, sebagai sebuah konseling 
Raputallang berfungsi untuk membantu masyarakat Toraja mengalami dan merasakan keadilan sosial. Hal tersebut sejalan dengan pernyataan Lee yang disadur oleh Judith A Lewis: orientasi keadilan sosial merupakan sebuah upaya dalam rangka menghadirkan kesetaraan yang didalamnya memastikan individu atau kelompok agar berpartisipasi penuh dalam masyarakat atau individu yang terpinggirkan berdasarkan ras / etnis, jenis kelamin, usia, cacat fisik atau mental, pendidikan, orientasi seksual, status sosial ekonomi atau karakteristik lain yang berasal dari latar belakang masyarakat.

Salah satu strategi pendekatan konseling masyarakat yang dapat dibangun dari Raputallang adalah model Hipotetik. Model Hipotetik ini dibangun berdasarkan nilai filosofis dan nilai spiritual yang terakomodir dalam Simbol Raputallang sebagaimana yang telah dipaparkan sebelumnya. Adapun desain tersebut yang terejawantahkan melalui bagan, sebagai berikut :

\begin{tabular}{|c|c|c|c|}
\hline & \multicolumn{2}{|c|}{ Simbol Raputallang } & \\
\hline & Konsep Raputallang & & \\
\hline NilaiSpiritual & Pendekatan & Masalah & Tujuan \\
\hline Kasirampunan & $\begin{array}{l}\text { Kesadaran Nilai } \\
\text { Budaya }\end{array}$ & $\begin{array}{l}\text { Pudarnya Nilai } \\
\text { Kebersamaan }\end{array}$ & $\begin{array}{l}\text { Mengahadrikan } \\
\text { kesadaran mengani } \\
\text { pentingnya } \\
\text { kebersamaan }\end{array}$ \\
\hline Mabulo Lollong & & $\begin{array}{l}\text { Mengikisnya Nilai } \\
\text { Kejujuran }\end{array}$ & $\begin{array}{l}\text { Memberikan } \\
\text { pemahaman bahwa } \\
\text { pentingnya kejujuran }\end{array}$ \\
\hline Kinawa & & $\begin{array}{l}\text { Melemahnya Nilai } \\
\text { Kebijaksanaan }\end{array}$ & $\begin{array}{l}\text { Meningkatkan nilai } \\
\text { kebijaksanaan }\end{array}$ \\
\hline Siangkaran & & $\begin{array}{l}\text { Turunnya Nilai } \\
\text { Gotongroyong }\end{array}$ & $\begin{array}{l}\text { Memberikan } \\
\text { pemahaman } \\
\text { pentingnya sikap } \\
\text { Gotong Royong }\end{array}$ \\
\hline Sitiroanan & & $\begin{array}{l}\text { Tidak adanya sikap } \\
\text { saling melindungi }\end{array}$ & $\begin{array}{l}\text { Memberikan } \\
\text { wawasan pentingnya } \\
\text { untuk saling } \\
\text { melindungi }\end{array}$ \\
\hline Tuo Lan Mintu Agan & & $\begin{array}{l}\text { Kurangnya kesadaran } \\
\text { untuk menjalani setiap } \\
\text { kondisi hidup }\end{array}$ & $\begin{array}{l}\text { Menghadrikan } \\
\text { kesadaran untuk } \\
\text { selalu siap sedia } \\
\text { dalam setiap kondisi }\end{array}$ \\
\hline Keangga & & $\begin{array}{l}\text { Tidak Mampu Berguna } \\
\text { Bagi Orag Lain }\end{array}$ & $\begin{array}{l}\text { Menghadirkan } \\
\text { gagasan bahwa kita } \\
\text { harus berguna bagi } \\
\text { orang lain }\end{array}$ \\
\hline
\end{tabular}




\section{Langkah pendekatan konseling masyarakat Toraja menggunakan Raputallang}

Berikut penjelasan mengenai langkah konseling masyarakat Toraja menggunakan simbol Raputallang melalui pendekatan kesadaran nilai budaya:

Konseling masyarakat merupakan sebuah upaya pendampingan secara menyeluruh yang dilakukan oleh konselor sebagai upaya membantu konseli untuk keluar dari masalah dan menemukan kembali jati dirinya. Hal ini, sejalan dengan pernyataan Engel yang menyatakan proses konseling masyarakat merupakan sebuah upaya yang dilakukan dalam rangka untuk memanusiakan manusia, sehingga dalam proses konseling mengandung makna pemberdayaan terhadap manusia.

Memudarnya serta mengikisnya nilai kebersamaan, kejujuran, kebijaksanaan, gotong royong, saling melindungi, hidup dalam segala kondisi, berguna bagi yang lain ditengah masyarakat, mengakibatkan orang Toraja rentan menghidupi prinsip individualis, serakah, arogan, angkuh dan mudah menyerah dalam menjalani kehidupan, dengan keadaan seperti ini membuat mereka terjerumus pada masalahmasalah, seperti: pembunuhan, perkelaihan baik melibatkan pribadi lepas pribadi maupun komunitas, perebutan harta warisan, bunuh diri, pertengkaran antara keluarga, korupsi yang membuat mereka mengalami degradasi terhdap nilai hidup.

Pendekatan kesadaran nilai budaya merupakan sebuah langkah awal yang dilakukan oleh individu maupun masyarakat untuk menghadirkan, mengingat serta mempertahankan nilai-nilai yang terakomodir dalam kebudayaan yang ada dalam suatu masyarakat guna dipakai untuk mengkontruksi kehidupan mereka yang telah mengalami permasalahan sehingga dapat hidup sebagaimana adanya. Budaya merupakan sistem (dari pola tingkah laku yang diturunkan secara sosial) yang bekerja menghubungkan komunitas manusia dengan lingkungan ekologi mereka.

Dengan kata lain melalui pendekatan kesadaran budaya masyarakat Toraja terbantu untuk menghadirkan, mengingat dan mempertehankan serta mengaktualisasikan nilai-nilai budaya khususnya yang terakumulasi dalam simbol Raputallang; sebab nilai yang terakomodir dalam kebudayaan memiliki fungsi untuk mendorong dan mengarahkan manusia dalam membentuk diri mereka melalui tindakan-tindakan yang dinampakkan dalam kehidupann sosial. Melalui pendekatan kesadaran terhadap nilai budaya khususnya simbol raputallang masyarakat atau individu yang berada dalam masalah dapat menolong diri mereka untuk mengatasi permasalahan tersebut sebagai sebuah upaya membantu diri mereka untuk keluar dari belenggu jiwa.

Ditinjau dari sisi konseling masyarakat pendekatan kesadaran budaya memiliki tujuan yang selaras dengan konsep konseling sebagaimana diungkapkan oleh Katrhyn Geldard dan David Geldard, konseling pada hakikatnya memiliki tujuan untuk menolong orang lain menyelesaikan masalah yang menggangu kehidupan mereka. Selain itu konseling juga dimaksudkan untuks membantu klien mengembangkan segala cara yang lebih positif untuk menyikapi hidup yang dijalani. Pendekatan kesadaran budaya berfungsi untuk membantu masyarakat Toraja mengatasi pudarnya nilai-nilai kebersamaan yang melekat pada kehidupan mereka. 


\section{Kesimpulan}

Pada dasarnya setiap umat manusia yang menghadapi masalah membutuhkan sebuah proses konseling sebagai upaya membantu mereka keluar dari masalah dan kembali menemukan "semangat hidupnya", tak terkecuali masyarakat Toraja. Sebagai sebuah kebudayaan Raputallang dalam masyarakat Toraja tidak hanya menjadi falsafah hidup, melainkan dapat berfungsi sebagai sebuah media konseling masyarakat Toraja, sebab Raputallang,melalui nilai-nilai yang terakomodir di dalamnya mampu menegur, mengevaluasi serta mengkonstruksi kehidupan masyarakat menjadi lebih baik.

\section{Referensi}

Clifford, Geertz. Tafsir Kebudayaan, Yogyakarta: Kanisius, 1992.

Daan, Engel Jacob. Konseling Masalah Masyarakat, Yogyakarta: PT Kanisius, 2018. . Konseling Pastoral dan Isu-isu Kontemporer, Jakarta: BPK Gunung Mulia, 2016.

Hutabarat, Lebang Henriette, Tiku Rari, Christian Tanduk, dkk. Sejarah Gereja Toraja 1913-2013, Tana Toraja: Institute Teologi Gereja Toraja, 2011.

Kathryn, Geldard dan David Geldard. Membantu Memecahkan Masalah Orang Lain dengan Tehknik Konseling, Yogyakarta: Pustaka Pelajar 2018.

KBBI Online, https://kbbi.web.id, (diakses 4 April 2019).

Lewis, Judith A., Michael D. Lewis, dkk. Community Konseling-A Multicutural - Sosial Justice Persfektif, United States of America 2011.

Montilla, Esteban. Jurnal: Counseling in the República Bolivariana de VenezuelaBolivarian Republic of Venezuela 2009.

Oktaviandi, Rantelino. "Simbolisme Tongkonan Persfektif Alukta" Sebuah Telaa Kritis, Magister, Tesis, Universitas Satya Wacana Salatiga, 2011.

Pon, Michael Nai Chiu (ed). Pilgrims and Citizens: Christian Social Engagements In East Asian Today, Adelaide: ATF Press, 2006

Pangarungan, Daud Arung. "Wawancara”, Toraja, Indonesia, 05 Agustus 2018

Rante, Urbanus Sampe. "Wawancara oleh penulis," Toraja, Indonesia, 29 Juli 2018.

Ruruk, Yohanis. "Wawancara oleh penulis," Toraja, Indonesia, 10 Agustus 2018.

Susabda, Yakub B. Konseling Pastoral-Pendekatan Konseling Pastoral Berdasarkan Integrasi Teologi dan Psikologi, Jakarta: BPK Gunung Mulia 2014.

Tribunnews, http://makassar.tribunnews.com/2019/03/08/angka-kasus-bunuh-dirimeningkat-di-toraja-2019-sudah-7-kasus, (diakses pada tanggal 06 Juni 2019). 